\title{
Murai Batu's (Copsychus malabaricus) Peak Frequency Sound: The Impact Toward Stomatal Pores of the Cayenne Pepper (Capsicum frutescens L) Leaves
}

\author{
Eka Sobiatin*1, Herianto $^{2}$, Nur Khosiyatun ${ }^{3}$, Mirra Fatharani ${ }^{4}$, Heru Kuswanto ${ }^{5}$ \\ ${ }^{1,2,3}$ Science Education Department, Yogyakarta State University, Yogyakarta, Indonesia \\ ${ }^{4}$ Master of Education in Expert Teaching Practice, Monash University, Wellington Rd, Australia \\ ${ }^{5}$ Physic Education Department, Yogyakarta State University, Yogyakarta, Indonesia
}

*Corresponding Address: ekasobiatin.2018@student.uny.ac.id

\begin{tabular}{|c|c|}
\hline Article Info & ABSTRACT \\
\hline Article history: & Cayenne pepper (Capsicum frutescens L) is one of Indonesian most favorite \\
\hline $\begin{array}{l}\text { Received: May 15th, } 2019 \\
\text { Accepted: October 8th, } 2019 \\
\text { Published: October } 30^{\text {th }}, 2019\end{array}$ & $\begin{array}{l}\text { chili called cabai rawit while Murai Batu (Copsychus malabaricus) is one of } \\
\text { the Indonesian bird which has a distinctive sound. This bird is widely found } \\
\text { in the territory of Indonesia, therefore, it is exciting to combine cayenne } \\
\text { pepper and Murai Batu into a study. This study aims to determine the effect }\end{array}$ \\
\hline $\begin{array}{l}\text { Keywords: } \\
\text { cayenne pepper; } \\
\text { murai batu; } \\
\text { sound frequency; } \\
\text { stomatal pores area. }\end{array}$ & $\begin{array}{l}\text { of Murai Batu's sound toward stomatal pores of the cayenne pepper leaves. } \\
\text { Two months old cayenne was used in this study. The sound of Murai Batu } \\
\text { was obtained by directly recording it using a recording device. The sound } \\
\text { recorded was then inserted into the sound analyzer software. The recording } \\
\text { of Murai Batu's sound was exposed to the cayenne pepper plant, particularly } \\
\text { its leaves. The stomatal pores area of cayenne leaves were observed under a } \\
\text { computer-connected microscope. The results of the study show that Murai } \\
\text { Batu's sound affects the area of the stomatal pores. The benefit of this study } \\
\text { is to provide information regarding the potential of the Murai Batu's sound } \\
\text { to increase the photosynthesis process of cayenne leaves by looking at the } \\
\text { sound effects of birds' chirping on the stomatal pores leaves the area. }\end{array}$ \\
\hline
\end{tabular}

(C) 2019 Physics Education Department, UIN Raden Intan Lampung, Indonesia

\section{INTRODUCTION}

Cayenne pepper is a leading Indonesian commodity that has high economic value (Rifki et al., 2017). One type of cayenne which is widely consumed and has high economic value is cayenne pepper (Capsicum frutescens.). The commodity consumption of cayenne pepper in Indonesia is high, in fact, Indonesia often imports cayenne because domestic production is overflowing, for example in August 2018, Indonesia imported cayenne pepper by 4,344,130 kg (BPPP The Ministry Of Trade, 2018).

Cayenne pepper (Capsicum frutescens L.) belongs to important horticultural commodities with very good prospects of business opportunities. Generally, cayenne pepper contains nutrients and vitamins, including calories, protein, fat, carbohydrate, calcium, vitamin A, Vitamin B1, and Vitamin C (Cao et al., 2016; Nathania ., Paulus A., \& Ellen G., 2016). Small pores on the surface of the leaf and the stem, limited by a pair of guard cells, that control gas exchange is called stomata (Jingjing et al., 2018). The stomatal pores are visible as a microscopic structure in the leaf epidermis formed by two special protective cells that control the exchange of water vapor and $\mathrm{CO} 2$ between plants and the atmosphere. The size of the stomata (S) and density (D) determines the maximum diffusion conductivity (stomata) of $\mathrm{CO}_{2}$ (gcmax) to the location of assimilation 
(Hasanuzzaman et al., 2018; Sicard et al., 2016).

Stomata are also responsible for controlling gas exchange, namely water vapor and $\mathrm{CO} 2$, between the inside and outside of the leaf. In this capacity, they make a major contribution to the ability of the stomata to control the relationship between water and to obtain carbon (Jingjing et al., 2018). Gas exchange is regulated by controlling the opening of the stomatal pores and the number of stomata that form on the epidermis. Stomatal measurements can refer to stomata areas that can be measured using analysis of stomata images that show parts of the stomatal pores opening, the length, and width of guard cells and the length of the stomatal pores (Papanatsiou, Amtmann, \& Blatt, 2016).

Communication between organisms is found throughout nature and it is one of the most thoroughly examined subjects in science. Plants perceive signal and respond to it according to their perception. It is obtained from light, electromagnetic, physical, acoustic or chemicals. Signals play an important role in communication or organism orientation (Schöner, Simon, \& Schöner, 2016). The evidence developing in the last two decades shows that the frequency of certain sound vibrations can positively influence processes such as seed germination (Gagliano, Renton, Duvdevani, Timmins, \& Mancuso, 2012), root elongation, callus growth (Emran, Chowdhury, Lim, \& Bae, 2014), and control the openings and stomata development (Silva and Dobránszki 2014). Sound and light can interact. The sound energy and light energy can convert and store chemical energy and increase the rate of photosynthesis (Mohanta, 2018; Sicard et al., 2016).

It is also important to note that there is no part of the plant that is free from the sound, both sounds that come from organisms such as bees buzzing or bird and those produced physically through wind gusts, running water, etc. Research on plant sensitivity toward sound vibrations from various ecologically relevant frequencies has been widely developed (Mohanta, 2018). Technology that utilizes sound waves has been applied to various plants. Various variations of research on sound waves that differ in frequency, sound pressure level (SPL), exposure period, and distance from sound sources can affect the growth of the plant. An example of a part of a plant that can be affected by sound is seed germination and stomata (Margaret E. Collins and John E.K. Foreman, 2001; Tapar Kumar Mohanta, 2018).

Sonic bloom technology was introduced by Dan Carlson in 1986. His results suggest that certain frequencies can help plants breathe better and absorb more nutrients. $\mathrm{He}$ found sounds like birds singing in the morning with a peak frequency of 3000 to 5000 hertz (Pujiwati \& Djuhari, 2014) will open and widen the stomata opening which affects the opening of the leaf stomata and increase plant's photosynthetic rate (Pujiwati, Aini, Sakti, \& Guritno, 2018). The stomatal opening is influenced by light, temperature, and other factors. However, by using scattered sound waves, the stomata can be opened to the maximum regardless of the factors above.

The sound sources that we encounter in nature are very diverse, one of which is the sound produced by various species of birds. Caring for birds singing is a popular hobby in Indonesian society. Many people are interested in the beauty of their feathers and recently the singing of birds has also become a prima donna for bird lovers (Saputro, Khaira, \& Tintin, 2016). Murai Batu is a type of bird that cannot be separated from the species of birds with tweets that can attract the attention of bird lovers and it is often used as a pet bird at home.

Murai Batu, with the Latin name Copsychus malabaricus is a member of the Turdidae family. The family of Turdidae is well known for their chirping ability. Their chirp is very melodious, musical, and its 
peak frequencies are varies greatly (Saputro et al., 2016). The sound peak frequency that can be used for exposure according to the sonic bloom theory is $3500-5000 \mathrm{~Hz}$ (Istirochah \& Sugiarto, 2017). Murai Batu has a frequency of $1000 \mathrm{~Hz}$ to $5000 \mathrm{~Hz}$ so that the sound range of Murai Batu can be used as exposure to observe the area of the stomatal pores.

The influence of sound on plants has been thoroughly studied by various countries such as Indonesia, Korea, and India. Several studies have shown that this technique affects the opening of the stomata of a rice plant. This study aims to determine the effect of sound waves on open rice plant stomata using sonic bloom technology. The results show that rice plant stomata have the largest width when the plants are given a sound with a frequency of $4 \mathrm{kHz}$ (Nadliroh, S. Widodo, \& R. Santoso, 2016). Other studies show that maintaining stomata opening at optimal width through harmonic frequency and sound intensity will increase the stomatal opening of soybean. Yields of soybean plants affected by sound waves with a frequency of $4 \mathrm{kHz}$ showed an increase of $26.2 \%$ (Pujiwati et al., 2018). Another research showed an audible sound affected the productivity of microalgae Picochlorum oklahomensis. This study demonstrates that the sounds heard by algae at a frequency of $2200 \mathrm{~Hz}$ are the most effective in terms of biomass production and volumetric oil yield. (Cai, Dunford, Wang, Zhu, \& He, 2016). This study is supported by previous research which shows that sound increases the transcription of certain genes, soluble protein content, and as one of the growth promoter/regulator (Mishra, Ghosh, \& Bae, 2016).

Sound waves from animals are one of the most important communication media. communication mechanism in animals is carried out by various specialized organs such as ears, antennas, and others. However, plants do not have special organs to hear sounds and only feel the sound signals (Mohanta, 2018). Acoustic communication is widespread and well studied in animals, but other organisms such as plants are rarely studied (Schöner et al., 2016). The effect of sound waves on plants allows us to learn about the environment using acoustic energy. This study is conducted to determine the effect of exposure to the sound of Murai Batu with the peak frequency of $5000 \mathrm{~Hz}$ toward the area of the stomatal pores of cayenne pepper leaves. This study is expected to inform another benefit of Murai Batu's sound. The chirping sound of Murai Batu can also have a positive impact to widen the stomatal pores.

\section{METHODS}

\section{Research Object}

The subject research of this study is cayenne pepper (Capsicum frutescens $L$ ). The equipments used in this study are mobile phone voice recorder application, the sound of the Murai Batu which its frequency has been adjusted using sound analyzer software, laptop speakers, laptop, 2-monthold cayenne pepper plant, digital microscope connected to the computer which has NIS element viewer applications, glass and glass cover objects, transparent mica plastic, and Alteco glue.

According to the voice analyzer software, the analysis of Murai Batu's sound could only be done by changing the file format of the recording from .mp3 to .wav. Murai Batu has an overall frequency of $2217 \mathrm{~Hz}$ and a peak frequency ranged between 3000 $5000 \mathrm{~Hz}$. In this research, we will expose the cayenne pepper with the adjusted peak frequency of $5000 \mathrm{~Hz}$.

\section{Research Procedure}

To adjust the bird`s sound frequency, the sound analysis was carried out twice. The recording of the original sound after being inserted into the sound analyzer software had an overall frequency of $2217 \mathrm{~Hz}$. So that the process of cutting the sound was needed to get the peak frequency. The sound analysis was carried out to determine the spectrum and frequency of the sound and 
then cut it with the overall frequency of $2217 \mathrm{~Hz}$ to be the sound with a duration of $1,240 \mathrm{~s}$ and have a peak frequency of 5000 $\mathrm{Hz}$.

The two cayenne pepper plants used in this study were two months old cayenne (Capsicum frutescens $L$ ). The cayenne plant was then divided into two parts, plants that are not exposed to the sound waves of the Murai Batu (control) and plants that had been exposed to the sound waves of the Murai Batu (treatment). The treated cayenne plants were exposed to the sound of a Murai Batu (frequency $5000 \mathrm{~Hz}$ ) for 2.5 hours. The cayenne plant's leaves, both the control and the treatment leaves, were then picked and made to be specimen using alteco glue and mica plastic by applying alteco glue on cayenne pepper leaves and sticking them on top of the mica plastic. After the leaves microscope slide set was successfully made, they were taken to a biology laboratory to be observed using a digital microscope that had been connected to a computer.

\section{Data Analysis}

Analysis of the Murai Batu's sound can be analyzed using sound spectrum analyzer software to obtain the expected frequency peak. The stomatal pores area can be known through the use of ImageJ software. The stomata pore area data obtained was calculated on average and compared between the data on the control and treatment plants.

When using ImageJ software to calculate the area of the stomatal pores, it is necessary to adjust the scale using a reference scale on the microscope. By using the Analyze menu; Set Scale, and enter the known distance value. According to the data of stomatal pores length, the distance value was equal to $50 \mu \mathrm{m}$.

Quantitative and more accurate stomatal pores area data was obtained by using the software on the computer. The data can be used to compare the exposed and the unexposed stomatal pores.

\section{RESULTS AND DISCUSSION}

The research was carried out by exposing the sound waves of the Murai Batu's peak frequency of $5000 \mathrm{~Hz}$ on cayenne pepper leaves. The aim of this study is to know the difference of stomatal pores between unexposed leaves of cayenne pepper and the exposed one. The Murai Batu (Copsychus malabaricus) sound used in this study had been cut and adjusted which resulted in a peak frequency of $5000 \mathrm{~Hz}$.

The selection of the bird species used for this study is according to the sonic bloom theory. It states that the best peak frequency for plants is approximately between 3500 $\mathrm{Hz}-5000 \mathrm{~Hz}$, therefore, Murai Batu was selected. The recording of the Murai Batu chirping was converted into a .wav form and was analyzed by the sound analysis software. The Waveform image of the sound is shown in Figures 1 and 2.

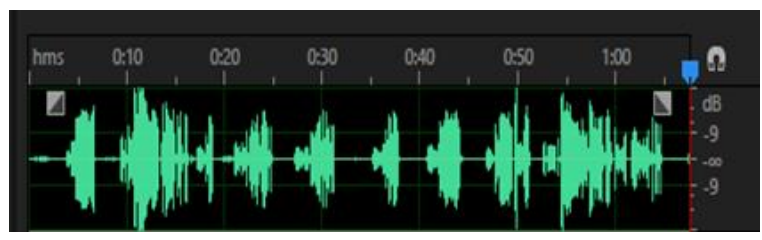

Figure 1. The Waveform of the Murai Batu's Sound

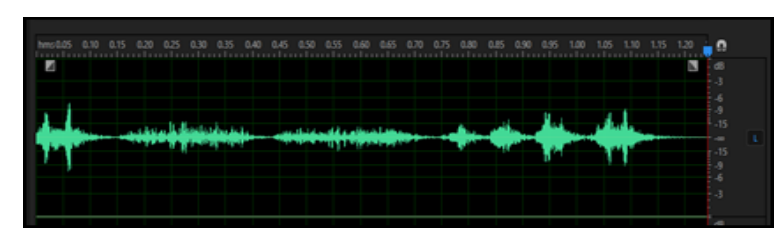

Figure 2. The waveform of the overall frequency of $2217 \mathrm{~Hz}$ and the adjusted peak frequency of $5000 \mathrm{~Hz}$

Figure 1 is the original form of the wave sound by Murai Batu which has an overall frequency of $2217 \mathrm{~Hz}$ and peak frequency range from 3000 to $5000 \mathrm{~Hz}$. In this study, the peak frequency was adjusted to $5000 \mathrm{~Hz}$ which was taken from one of the sound syllables of Murai Batu as shown as a waveform in Figure 2. The Waveform was inserted into the sound analysis software resulted in the syllable pieces of Murai Batu's sound obtained as shown in Figure 2. 


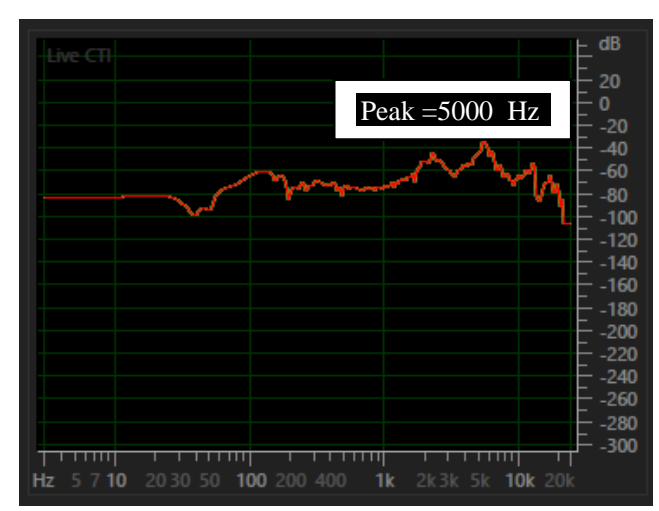

Figure 3. Peak Frequency Spectrum of $5000 \mathrm{~Hz}$ of Murai Batu

Figure 3 is the peak frequency Waveform. The peak frequency was analyzed by using sound spectrum analysis software. So that a peak frequency of 5000 $\mathrm{Hz}$ and a large peak frequency can be used as a sound that will be exposed to the cayenne pepper plant

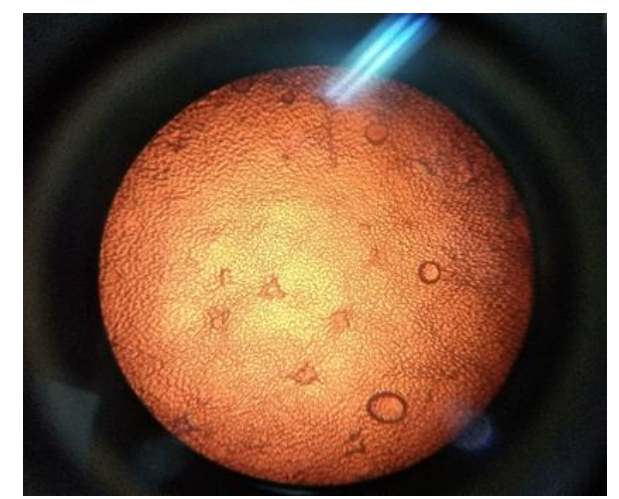

Figure 4. Results of Stomatal Observation under a Microscope of 40x Magnification

Figure 4 is the result of stomatal observation without using a microscope connected to a computer application. The figure shows several stomatal pores on the cayenne leaves that have been exposed to the Murai Batu's sound. The stomatal pores might not be seen properly through a light microscope, as shown in Figure 4.

Therefore, the stomatal specimen must be observed under a digital microscope that has been connected to the computer that has a microscopic picture imaging application on a computer screen.

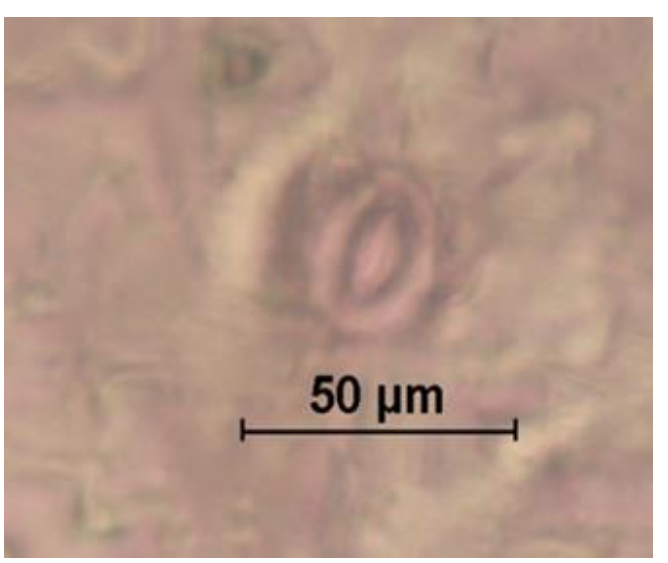

Figure 5. The Stomata of Cayenne Leaves Given Exposure to the Sound of Murai Batu (Copsychus malabaricus)

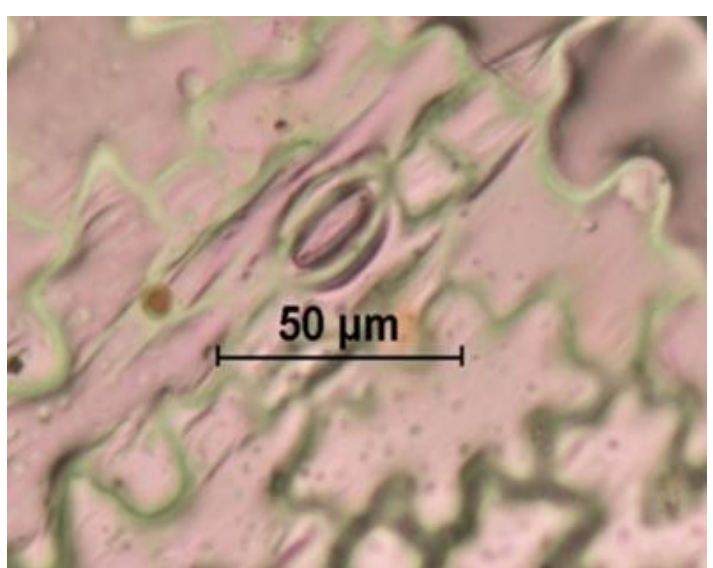

Figure 6. The Cayenne Leaf Stomata without the Treatment Using Murai Batu's Sound (Copsychus malabaricus) (Control)

The data was obtained by using a digital microscope (400x magnification) which was connected to a computer with a NIS element viewer. It can be seen in Figures 5 and 6 . Both of those figures depicted significant differences between the control microscope slide set (without sound exposure) and the treatment microscope slide set (exposure by sound). The stomatal pores exposed to the Murai Batu's sound are considered to be wider than the unexposed specimen.

To obtain quantitative data related to the differences, and analysis of the area of the stomatal pores was carried out. The stomatal pores area of cayenne leaves can be observed through ImageJ, as shown in Figure 7. 


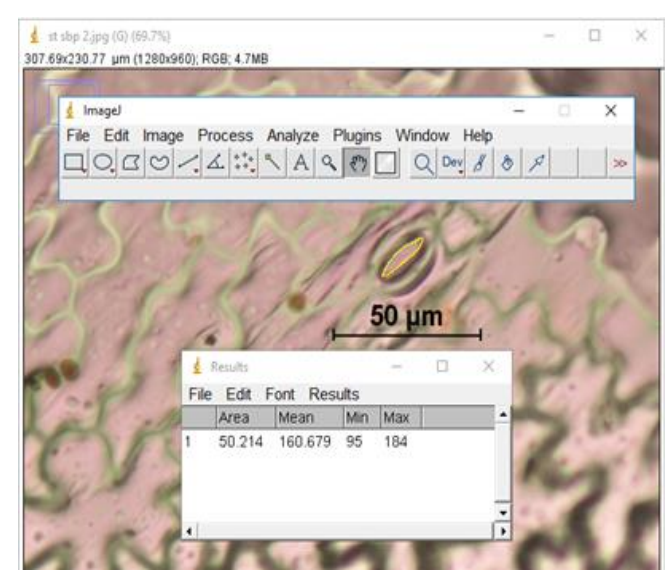

Figure 7. Examples of Stomatal Area Measurement Using Image J Software

Table 1. Stomatal Pores Area of Cayenne pepper

\begin{tabular}{|c|c|c|}
\hline \multirow[t]{2}{*}{ Leaf } & \multicolumn{2}{|c|}{$\begin{array}{l}\text { Stomatal Pores Length of } \\
\text { Cayenne pepper leaf }\end{array}$} \\
\hline & $\begin{array}{l}\text { Control } \\
\left(\mu \mathrm{m}^{2}\right)\end{array}$ & $\begin{array}{c}\text { Experimental } \\
\left(\mu \mathrm{m}^{2}\right)\end{array}$ \\
\hline PH1D1 & 58,708 & 85,057 \\
\hline PH1D2 & 50,214 & 82,200 \\
\hline PH1D3 & 67,664 & 96,608 \\
\hline PH1D4 & 30,972 & 88,322 \\
\hline PH1D5 & 42,066 & 60,147 \\
\hline Average & 49,924 & 82,466 \\
\hline
\end{tabular}

Based on the data in table 1 , it is clear that there are differences in the stomatal pores are exposed by Murai Batu's sound. The average of the control stomatal pores area is $49.924 \mu \mathrm{m}^{2}$ while the treatment is $82.466 \mu \mathrm{m}^{2}$. The largest exposed stomatal pores area is $96.608 \mu \mathrm{m}^{2}$.

The stomatal pores area of the cayenne leaves is graphically displayed in Figure 8.

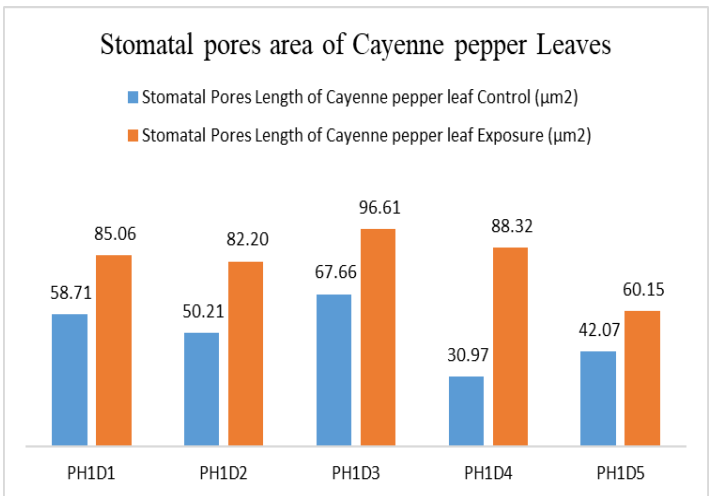

Figure 8. Graph of the Stomatal Pores Area of the Cayenne Pepper Plant
The results of leaf microscope slide sets $1,2,3,4$, and 5 respectively obtained stomatal pores area of 58,708 $\mu^{2}$; 50,214 $\mu^{2}$; $67,664 \mu \mathrm{m}^{2} ; 30,972 \mu \mathrm{m}^{2}$; and 42, $066 \mu \mathrm{m}^{2}$ while it was seen that the stomata area obtained in leaves $1,2,3,4$, and 5 which were exposed to bird sounds was 85,057 $\mu \mathrm{m}^{2}$; 82,200 $\mathrm{m}^{2}$; 96,608 $\mu \mathrm{m}^{2} ; 88,322 \mu \mathrm{m}^{2}$; and $60,147 \mu^{2}$. The results obtained from the graph show that the sound waves of Murai Batu affect the cayenne pepper stomatal openings It can be seen from the five samples of the leaf. The microscope slide set shows an increase in the number of stomatal pores areas compared to the unexposed leaf.

The opening of the stomata is caused by the influence of the Murai Batu's acoustic frequency. It can increase the osmotic pressure and cell size results in the opening of stomata. The larger the stomatal opening, the more benefit the plant can get. These benefits are nutrients and other ingredients in the leaves which become more effectively absorbed compared to plants without exposure to the sound of the Murai Batu.

The process of stomatal opening is essential because $\mathrm{O}_{2}$ gas diffuses out of the plant, and $\mathrm{CO}_{2}$ gas enters the cell as the main ingredient in the process of photosynthesis aided by sunlight. This photosynthesis process will directly affect the respiration process that produces energy in the form of ATP.

Sound waves exposed to the plants/leaves produce enough energy. The energy of these sound waves can increase turgor pressure, This makes stomata open up. The opening or closing mechanism of the stomata is a complex event. It occurs because of changes or turgor settings in closing the cells (Nadliroh et al., 2016). The opening and closing of the stomata using sonic bloom technology can occur because the sound waves exposed to cayenne pepper will resonate and will increase cytoplasmic movement, causing microbubbles that will push the guard cell out and cell turgor 
pressure will increase so that the stomata are opened.

The results obtained are in line with the results of previous studies which show that the width of the stomata openings on cucumber leaves exposed to sound has a greater average area than the unexposed one (Desiliani \& Ratnawati, 2018). Sound wave exposure can also increase the width of soybean leaf stomata compared to controls (Istirochah \& Sugiarto, 2017). The results are also supported by the previous research by (Pujiwati \& Djuhari, 2011) that show the stomatal opening increases when the sound frequency is $4-5 \mathrm{kHz}$. However, if the frequency reaches $6-7 \mathrm{kHz}$, the stomatal opening will decrease. Previous research (Emran et al., 2014) reports that certain frequencies and intensities can have a positive effect on various biological indices of plants, including seed germination, root length, plant height, callus growth, cell cycle, transduction, enzymatic signaling, and hormonal activity and gene expression.

The results of the study showed that the treated plants had a wider stomatal pores area compared to the control plants.

This study might provide an opportunity for the community to combine the chirping of birds and plants to obtain better productivity. Especially in terms of the width of stomatal pores opening that can improve photosynthesis.

\section{CONCLUSION}

The average of stomatal pores area on cayenne pepper leaves (Capsicum frutescens $L$ ) exposed by Murai Batu's adjusted peak frequency sound of $5000 \mathrm{~Hz}$ is larger than the unexposed one. The average of the control stomatal pores area is $49.924 \mu^{2}$ while the treatment is $82.466 \mu^{2}$. The largest exposure stomatal pores area is $96.608 \mu \mathrm{m}^{2}$. Limitations of the plant type used as a sample and the frequency are separate notes in this study as things to be paid more attention in the future. This research can be continued by increasing the number of plant samples with exposure to varied bird sounds frequency then the information obtained from this study will continue to grow.

\section{ACKNOWLEDGMENT}

My acknowledgment is given to LPDP (Indonesia Endowment for Education) and Yogyakarta State University (UNY). I would like to express my special thanks for gratitude to LPDP who has provided me with a scholarship to continue my education. Financial support from LPDP has helped me to finish this research too, and I am so grateful to it.

\section{AUTHOR CONTRIBUTIONS}

ES determines the concept and design of the research. ST collects the object to be studied and records the results of the research on the sound of the Murai Batu bird from the recording device. NK does the calculations and outlines the results. MF describes the discussion of the data that has been obtained. HK wrote the article.

\section{REFERENCES}

BPPP The Ministry of Trade. (2018). Angka Impor Cabai Indonesia.

Cai, W., Dunford, N. T., Wang, N., Zhu, S., \& He, H. (2016). Audible Sound Treatment of the Microalgae Picochlorum Oklahomans for Enhancing Biomass Productivity. Bioresource Technology, 202, 226230.

https://doi.org/10.1016/j.biortech.2015. 12.019

Cao, Z., Zhou, L., Bi, J., Yi, J., Chen, Q., $\mathrm{Wu}$, X., ... Li, S. (2016). Effect of Different Drying Technologies on Drying Characteristics and Quality of Red Pepper (Capsicum frutescens L.): a Comparative Study. Journal of the Science of Food and Agriculture, 96(10), 3596-3603. https://doi.org/10.1002/jsfa.7549

Desiliani, A., \& Ratnawati. (2018). Produktivitas dan Luas Stomata Tanaman Mentimun Dipengaruhi 
Variasi Konsentrasi Pupuk Organik dengan Pemaparan Suara. Jurnal Prodi Biologi, 7(5), 300-308.

Emran, M., Chowdhury, K., Lim, H.-S., \& Bae, H. (2014). Update on the Effects of Sound Wave on Plants, 20(1), 1-7. https://doi.org/10.5423/RPD.2014.20.1. 001

Gagliano, M., Renton, M., Duvdevani, N., Timmins, M., \& Mancuso, S. (2012). Out of Sight but not out of Mind: Alternative Means of Communication in Plants. PLoS ONE, 7(5), 37382. https://doi.org/10.1371/journal.pone.00 37382

Hasanuzzaman, M., Shabala, L., Zhou, M., Brodribb, T. J., Corkrey, R., \& Shabala, S. (2018). Factors Determining Stomatal and NonStomatal (Residual) Transpiration and Their Contribution Towards Salinity Tolerance in Contrasting Barley Genotypes. Environmental and Experimental Botany, 153, 10-20. https://doi.org/10.1016/J.ENVEXPBO T.2018.05.002

Istirochah, P., \& Sugiarto. (2017). Pengaruh Intensitas Bunyi terhadap Pembukaan Stomata, Pertumbuhan dan Hasil Kedelai (Glycine Max (L .) Merril ) melalui Aplikasi Sonic Bloom. Jurnal Folium, 1(1), 60-70.

Jingjing, H., Zhang, R. X., Peng, K., Tagliavia, C., Li, S., Xue, S., ... Hetherington, A. M. (2018). The Big Protein Distinguishes the Process of CO2-Induced Stomatal Closure from the Inhibition of Stomatal Opening by CO2. New Phytologist, 218(1), 232241. https://doi.org/10.1111/nph.14957

Margaret E. Collins and John E.K. Foreman. (2001). Effect of Sound on Growth of Plants. BioScience, 29(2), 621-622. https://doi.org/10.2307/1293410

Mishra, R. C., Ghosh, R., \& Bae, H. (2016). Plant acoustics: In the Search of a Sound Mechanism for Sound Signaling in Plants. Journal of Experimental Botany, 67(15), 4483-4494. https://doi.org/10.1093/jxb/erw235

Mohanta, T. K. (2018). Sound Wave in Plant Growth Regulation: A Review of Potential Biotechnological Applications. Journal of Animal and Plant Sciences, 28(1), 1-9.

Nadliroh, K., S. Widodo, C., \& R. Santoso, D. (2016). Analisis Pengaruh Frekuensi Bunyi terhadap System Buka Tutup Stomata Tanaman Padi Varietas Logawa. Natural-B, 3(2), 187-192. https://doi.org/10.21776/ub.naturalb.2015.003.02.13

Nathania ., P., Paulus A., P., \& Ellen G., T. (2016). Faktor-Faktor yang Mempengaruhi Harga Cabai Rawit di Kota Manado. Agri-Sosioekonomi, 12(2), 105-120.

Papanatsiou, M., Amtmann, A., \& Blatt, M. R. (2016). Stomatal Spacing Safeguards Stomatal Dynamics by Facilitating Guard Cell Ion Transport Independent of the Epidermal Solute Reservoir. Plant Physiology, 172(1), 254-263.

https://doi.org/10.1104/pp.16.00850

Pujiwati, I., Aini, N., Sakti, S. P., \& Guritno, B. (2018). The Effect of Harmonic Frequency and Sound Intensity on the Opening of Stomata, Growth and Yield of Soybean (Glycine max (L.) Merrill). Pertanika Tropical Agricultural Science, 41(3), 963-974.

Pujiwati, I., \& Djuhari. (2011). Determination Model Leaf Stomata Opening Soybean (Glycine max (L.) Merrill) as a Result of Exposure to High-Frequency Sound Waves. AGRITEK, 2(03), 636-642.

Pujiwati, I., \& Djuhari. (2014). The Pattern of Stomatal Opening Through the Exposure of High-Frequency Sound Wave with the Different Duration and Age of Soybeans (Glycine max (L.) Merril). Agricultural Science, 2(1), 6977. https://doi.org/10.12735/as.v2i1p69 Rifki Ardian, Wayan Sudarta, \& I Ketut Rantau. (2017). Perbandingan Pendapatan Usahatani Cabai Rawit 
dengan Menggunakan Pupuk Anorganik dan Pupuk Campuran (Organik, dan Anorganik) (Studi Kasus di Subak Kudungan, Desa Bontihing, Kecamatan Kubutambahan, Kabupaten Buleleng). Jurnal Agribisnis Dan Agrowisata (Journal of Agribusiness and Agritourism), 6(2), 240-248. https://doi.org/10.24843/jaa.2017.v06.i 02.p07

Saputro, D. A., Khaira, N., \& Tintin, K. (2016). Perilaku Burung Murai Batu (Copsychus malabaricus) Siap Produksi. Jurnal Ilmiah Peternakan Terpadu, 4(3), 222-229.

Schöner, M. G., Simon, R., \& Schöner, C. R. (2016). Acoustic Communication in Plant-Animal Interactions. Current Opinion in Plant Biology, 32, 88-95. https://doi.org/10.1016/j.pbi.2016.06.0 11
Sicard, P., Marco, A. De, Laurence, D.-R., Tagliaferro, F., Renou, C., \& Paoletti, E. (2016). An Epidemiological Assessment of Stomatal Ozone FluxBased Critical Levels for Visible Ozone Injury in Southern European Forests. Science of the Total Environment, 541, 729-741.

Tapar Kumar Mohanta. (2018). Sound Wave in Plant Growth Regulation: A Review of Potential Biotechnological Applications. The Journal of Animal \& Plant Sciences, 28(11-9).

Teixeira da Silva, J. A., \& Dobránszki, J. (2014). Sonication and Ultrasound: Impact on Plant Growth and Development. Plant Cell, Tissue and Organ Culture (PCTOC), 117(2), 131143. https://doi.org/10.1007/s11240014-0429-0 